\title{
A comparison of bull beef production from Friesian type and selected Jersey type calves
}

\author{
P.D. MUIR ${ }^{1}$, C.J. FUGLE ${ }^{1}$, N.B. SMITH ${ }^{1}$ and A.W.A ORMOND ${ }^{2}$ \\ ${ }^{1}$ AgResearch, Poukawa Research Station, P.O. Box 8144, Havelock North \\ ${ }^{2}$ Nurse and Ormond, P.O. Box 115, Waipukurau \\ paul.muir@agresearch.co.nz
}

\section{Abstract}

Three on-farm experiments were undertaken to examine the comparative performance of Friesian and selected Jersey $x$ Friesian bulls in intensive bull beef systems. In Experiment 1, Friesian, 1/4 Jersey $/ 3 / 4$ Friesian and $1 / 2$ Jersey $/ 1 / 2$ Friesian bulls were sourced as 4-day-old calves, reared together and farmed commercially through until slaughter at 29 months of age. When slaughtered at the same age, Friesian bulls averaged $290 \mathrm{~kg}$ carcass weight, with $1 / 4$ Jersey and $1 / 2$ Jersey bulls averaging 289 and $271 \mathrm{~kg}$, respectively. There was considerable variation in animal performance within the breed types, with the top $50 \%$ of the $1 / 2$ Jersey bulls averaging $553 \mathrm{~kg}$ liveweight and the bottom $50 \%$ of the Friesian bulls averaging $522 \mathrm{~kg}$ at 29 months of age. In Experiment 2, 31 rising 2-year-old Friesian type bulls $(436 \mathrm{~kg})$ and 32 rising 2 -year-old Jersey x type bulls $(423 \mathrm{~kg})$ were each allocated to two lanes of a Technosystem and stocked at $1828 \mathrm{~kg}$ liveweight $/ \mathrm{ha}$. Between May and November, Friesian type bulls produced $2.5 \%$ more beef liveweight per hectare than the Jersey x bulls (816 vs $796 \mathrm{~kg}$ of liveweight/ha). In Experiment 3, 43 rising 1-year-old Friesian type $(199 \mathrm{~kg})$ and 46 rising 1 -year-old Jersey $\mathrm{x}$ bulls $(185 \mathrm{~kg})$ were each allocated to two lanes of a Technosystem and stocked at $1016 \mathrm{~kg}$ liveweight/ ha. Between June and December, Jersey x type bulls produced $1 \%$ more liveweight/ha than the Friesian type bulls (1151 vs $1141 \mathrm{~kg}$ of liveweight/ ha). The Friesian type bulls outperformed the Jersey $x$ type bulls on a per head basis. Nevertheless there were a number of high performing Jersey $\mathrm{x}$ type bulls, suggesting that coat colour is not a suitable means of identifying better or poorer performing bulls. When Friesian type and Jersey $\mathrm{x}$ type bulls were stocked at a similar liveweight per hectare, there was little difference in terms of total output of beef per hectare. Since bulls are bought and sold on a liveweight basis, Jersey $\mathrm{x}$ type bulls can be as profitable as Friesian type bulls provided the purchase price is discounted to reflect the fact that more of them will be slaughtered in lower paying weight ranges. Our calculations indicate that on present prices, this discount for selected Jersey $x$ type bulls could be as little as $\$ 11$ per head to offset reductions in carcass value. Current discounts for Jersey $x$ type bulls are well in excess of this and may reflect the difficulties in re-selling Jersey $x$ type bulls and perceived behavioural problems with these bulls.

Keywords: bull beef, Friesian, Jersey, per head, per hectare

\section{Introduction}

New Zealand bull beef production systems are dependent on the dairy industry for a supply of surplus male calves. Whilst there is a strong demand for wellmarked Friesian calves, the actual supply of these calves has decreased over recent years because of a trend within the dairy industry towards cross breeding Friesians with Jerseys. As a result of these trends, only $57 \%$ of dairy cows are currently classed as Friesians. Moreover, $26 \%$ of these Friesian cows were inseminated with Jersey semen in the 1999 season (Anon 2000).

In spite of difficulties in sourcing Friesian bull calves, there is reluctance on the part of calf rearers to rear poorly marked calves because of a historical prejudice amongst beef finishers against Jersey $\mathrm{x}$ cattle. This is based on perceptions of slow growth rate and poor meat quality (principally yield and fat colour effects). Much of the early work involving Jersey $\mathrm{x}$ cattle dates back to the 1960s and was focused on lighter weight steers (Joblin 1966; Barton et al. 1994) and bulls (Everitt and Ward 1974). In bull finishing systems, fat colour is not an issue and in recent years, output of meat and profit per hectare have become more important than growth rate per se. The aim of the current work was to provide some preliminary data on the comparative output of bull beef on both a per head and per hectare basis using current Friesian type and Jersey $\mathrm{x}$ type genotypes.

\section{Methods}

\section{Experiment 1}

In August 1997, 64 Friesian, 25 1/4 Jersey/3/4 Friesian and $44 \frac{1}{2}$ Jersey $/ 1 / 2$ Friesian bull calves were sourced 
from Waikato dairy farms at approximately 4 days of age. Because no calves under $35 \mathrm{~kg}$ were selected, a high degree of selection pressure would have been placed on the Jersey type calves. Nevertheless, all the $1 / 4$ and $1 / 2$ Jersey calves used in this experiment would otherwise have been slaughtered for bobby veal because their coat colour and markings identified them as of "Jersey type". Calves were transported to the Poukawa Research Station in Hawke's Bay and reared together using a once-a-day milk feeding system (System 4, Muir et al. 2000). Calves were weighed on arrival at Poukawa, at weaning off milk at 5 weeks of age, and at 12 weeks of age. At 14 weeks of age, calves were transported back to the Waikato and farmed together under commercial conditions (generally set stocked) and slaughtered at approximately 29 months of age. During this time, bulls were weighed at 3-monthly intervals and, as behavioural problems increased, bulls were randomly split into smaller groups to simplify management. Pre-slaughter weights were recorded at 28 months of age (10 December 1999) and bulls were drafted for slaughter over the following 6 weeks.

\section{Experiment 2}

This experiment was undertaken at Matapiro in Hawke's Bay. Friesian type and Jersey $\mathrm{x}$ type rising 2-year-old bulls which had been reared and farmed together were allocated to two groups on 30 May 2000. For this experiment, allocation to groups simply involved selecting the Jersey $x$ type from within a mixed mob. The Jersey $x$ bulls selected tended to be the type with black legs and mottled markings and could be considered to represent the better "Jersey x type" animals. Each breed was split into two groups and randomly allocated to one of four 3.7-ha lanes of a Technosystem, an intensive livestock finishing system developed and marketed by Kiwitech (Ogle \& Tither 2000). Between 15 and 17 bulls were allocated to each lane so that starting liveweight was similar for each lane at $6763 \mathrm{~kg}$ per lane or $1828 \mathrm{~kg} / \mathrm{ha}$. Bulls were shifted onto fresh pasture every second day. Pre-grazing pasture cover was assessed by pasture probe at monthly intervals. All bulls were weighed at monthly intervals. Bulls were weighed prior to slaughter on 9 November 2000. Carcass weight and grade was recorded at slaughter for each bull.

\section{Experiment 3}

This experiment was undertaken at Takapau in Central Hawke's Bay. Forty-six rising 1-year-old Jersey x type bulls were purchased on 12 May 2000 and 43 Friesian type bulls were purchased on 6 June 2000 and allocated to treatment groups on 9 June 2000. Jersey $\mathrm{x}$ type bulls tended to be the more typical black and brown crossbred types with very few white markings. As in Experiment 1 , each breed was allocated to two lanes (replicates) of a Technosystem (each of $4.2 \mathrm{ha}$ ) so that total liveweights per lane were similar at $4266 \mathrm{~kg}$ or $1016 \mathrm{~kg} / \mathrm{ha}$. On 20 December, the mobs were further split because of declining pasture covers and one each of the Friesian type and Jersey $\mathrm{x}$ type mobs were moved and farmed in lanes of $8.78 \mathrm{ha}$. The remaining four lanes remained where they were but had their lanes doubled to 8.64 ha. Bulls were weighed on 24 August, 20 December 2000 and 18 April 2001. The trial ceased on 18 April 2001 as a result of drought conditions and low feed covers. Pre-graze pasture covers were assessed by pasture probe on 14 July, 25 August, 28 October and 21 November 2000 .

\section{Results and discussion}

\section{Experiment 1}

Friesian calves averaged $45 \mathrm{~kg}$ at the start of the experiment and the $1 / 2$ Jersey $\mathrm{x}$ calves were significantly $6 \mathrm{~kg}$ lighter $(\mathrm{P}<0.01)$ at $39 \mathrm{~kg}($ Table 1$)$. These differences increased throughout the experiment to be $37 \mathrm{~kg}$ by the time of slaughter. Although significantly lighter at slaughter $(\mathrm{P}<0.01)$, the $1 / 2$ Jersey $\mathrm{x}$ bulls still achieved carcass weights of $271 \mathrm{~kg}$. There was no significant difference between the carcass weights of the Friesian $(290 \mathrm{~kg})$ and $1 / 4$ Jersey x bulls $(289 \mathrm{~kg})$. Barton et al. (1994) and Candy \& McAdam (1966) also noted a close relationship between Friesian and Jersey $\mathrm{x}$ animals, albeit in steers and at much lighter liveweights. Nevertheless, the close relationship between Friesian type and Jersey $x$ type animals indicate that there is a degree of hybrid vigour which could make the farming of Friesian x Jersey bulls profitable.

Performance of bulls within each breed was highly variable, with the top $50 \%$ of the $1 / 2$ Jersey bulls averaging $553 \mathrm{~kg}, 30 \mathrm{~kg}$ heavier than the bottom $50 \%$

Table $₫ 1$ Liveweights and carcass weights $( \pm$ SEM) of Friesian $(F)$ and Jersey $(J)$ x bulls reared and farmed together for 29 months.

\begin{tabular}{lcccc}
\hline Genotype & $\begin{array}{c}\text { Start weight } \\
(\mathrm{kg})\end{array}$ & $\begin{array}{c}12 \text { week weight } \\
(\mathrm{kg})\end{array}$ & $\begin{array}{c}\text { Pre-slaughter weight } \\
(\mathrm{kg})\end{array}$ & $\begin{array}{c}\text { Carcass weight } \\
(\mathrm{kg})\end{array}$ \\
\hline Friesian & $44.8 \pm 0.54^{\mathrm{A}}$ & $100.1 \pm 1.33^{\mathrm{A}}$ & $559 \pm 5.58^{\mathrm{A}}$ & $290 \pm 3.07^{\mathrm{A}}$ \\
$1 / 4$ Jersey/3/4 Fresian & $42.2 \pm 1.08^{\mathrm{B}}$ & $96.3 \pm 3.07^{\mathrm{B}}$ & $553 \pm 12.16^{\mathrm{A}}$ & $289 \pm 6.70^{\mathrm{A}}$ \\
$1 / 2$ Jersey/1/2 Fresian & $39.2 \pm 0.68^{\mathrm{C}}$ & $88.2 \pm 1.65^{\mathrm{C}}$ & $522 \pm 8.36^{\mathrm{B}}$ & $271 \pm 4.23^{\mathrm{B}}$ \\
\hline
\end{tabular}

Values in the same column with different superscripts are significantly different $(P<0.01)$ 
of the Friesian bulls which averaged $522 \mathrm{~kg}$. Thus there is considerable scope for selecting the better Jersey $\mathrm{x}$ type calves for rearing and in rejecting the poorer Friesian type calves. At present, calves are currently selected for rearing on the basis of coat colour and markings. Selection of calves on the basis of weight and frame size may be more appropriate.

\section{Experiment 2}

Pasture covers averaged $3407 \mathrm{~kg} \mathrm{DM} / \mathrm{ha}$ at the start of the experiment on 30 May and pre-graze pasture covers averaged $2237 \mathrm{~kg} \mathrm{DM} / \mathrm{ha}$ through until slaughter on 9 November. At the start of the experiment, the 31 Friesian type bulls averaged $436 \mathrm{~kg}$ and the 32 Jersey $x$ type bulls averaged $423 \mathrm{~kg}$ (Table 2). Over the course of the experiment, the Friesian type bulls averaged $1.19 \mathrm{~kg} /$ day compared to $1.13 \mathrm{~kg}$ /day for the Jersey $\mathrm{x}$ type bulls. At slaughter, average carcass weight of the Friesian bulls was only $7 \mathrm{~kg}$ heavier, partly because of the slightly higher dressing out percentage of the Jersey $\mathrm{x}$ type bulls (Table 2). There was no significant difference between the breed groups in liveweight, liveweight gain or carcass weight. The Friesian type bulls produced $816 \mathrm{~kg}$ liveweight/ha compared with $796 \mathrm{~kg} / \mathrm{ha}$ for the Jersey $\mathrm{x}$ type bulls. Thus, in this study the Friesian type bulls produced an extra $20 \mathrm{~kg}$ of liveweight per hectare, an advantage of $2.5 \%$ in favour of the Friesian type bulls. However the higher dressing out percentage of the Jersey $\mathrm{x}$ type bulls meant that the carcass weight advantage of the Friesian type bulls was reduced to only $0.1 \%$ on a per hectare basis.

\section{Experiment 3}

Pre-graze pasture cover averaged $2407 \mathrm{~kg} \mathrm{DM} / \mathrm{ha}$ on 14 July, declining to $1659 \mathrm{~kg} \mathrm{DM} / \mathrm{ha}$ on 25 August. Pasture cover averaged 2750 and $3220 \mathrm{~kg} \mathrm{DM} / \mathrm{ha}$ on 28 October and 21 November, respectively. Friesian type bulls averaged $199 \mathrm{~kg}$ and Jersey $\mathrm{x}$ type bulls averaged $185 \mathrm{~kg}$ at the start of the experiment. Friesian type bulls were significantly heavier at the start and finish of the experiment $(\mathrm{P}<0.001)$ (Table 3$)$. During the first 76 days of the trial (i.e., over winter), liveweight gain differences between the two groups were quite marked, at 0.83 and $0.62 \mathrm{~kg} /$ day for Friesian type and Jersey $\mathrm{x}$ type bulls respectively. Over the full 313 days of the experiment, the liveweight gain differences were less marked, with Friesian type bulls growing at $0.97 \mathrm{~kg}$ / day compared to $0.90 \mathrm{~kg} /$ day for the Jersey $\mathrm{x}$ type bulls $(\mathrm{P}<0.001)$. The slower growth rates of the Jersey $\mathrm{x}$ type bulls during the winter appeared to be associated with greater activity (e.g., riding) and muddier residuals than was occurring in the adjacent lanes of Friesian type bulls. Whether this is a result of inherent behavioural differences between the breeds or attributable to the greater number of animals in each lane is not clear.

Bulls were maintained in their lanes from 9 June to 20 December and the total liveweight production per hectare was $1141 \mathrm{~kg}$ from the Friesian type bulls and $1151 \mathrm{~kg}$ from the Jersey $\mathrm{x}$ type bulls. In this situation Jersey $\mathrm{x}$ type bulls produced approximately $1 \%$ more liveweight gain/ha. From 20 December to 18 April, the size of each lane was increased equally so it has not been possible to calculate production per hectare

Table $\llbracket 2$ Liveweight, liveweight gains (LWG) and carcass weights of rising 2-year-old Friesian and Jersey $\mathrm{x}$ bulls stocked at a similar liveweight per ha and farmed in a Technosystem between May and November. Values in parentheses are \pm SEM.

\begin{tabular}{|c|c|c|c|c|c|c|c|}
\hline Breed & $\begin{array}{l}\text { Number } \\
\text { of bulls }\end{array}$ & $\begin{array}{c}\text { Start weight } \\
(\mathrm{kg})\end{array}$ & $\begin{array}{c}\text { Finish weight } \\
(\mathrm{kg})\end{array}$ & $\begin{array}{l}\text { LWG } \\
\text { (kg/day) }\end{array}$ & $\begin{array}{c}\text { Carcass weight } \\
(\mathrm{kg})\end{array}$ & $\begin{array}{c}\text { Dressing out } \\
\%\end{array}$ & LWG/ha \\
\hline Friesian & 31 & $436 \pm 5.76$ & $631 \pm 6.87$ & $1.19 \pm 0.04$ & $340 \pm 4.87$ & 53.8 & 816 \\
\hline $\begin{array}{l}\text { Significance } \\
(\mathrm{ns}=\mathrm{P}>0.05)\end{array}$ & & ns & ns & ns & ns & & \\
\hline
\end{tabular}

Table $₫ 3$ Liveweight and liveweight gains (LWG) of rising 1-year-old Friesian and Jersey $\mathrm{x}$ bulls stocked at a similar liveweight per ha and farmed in a Technosystem between June and April. Values in parentheses are \pm SEM.

\begin{tabular}{|c|c|c|c|c|c|c|}
\hline Breed & $\begin{array}{l}\text { Number of } \\
\text { bulls }\end{array}$ & $\begin{array}{c}\text { Start weight } \\
(\mathrm{kg})\end{array}$ & $\begin{array}{c}\text { Finish weight } \\
(\mathrm{kg})\end{array}$ & $\begin{array}{l}\text { LWG } \\
\text { (kg/day) }\end{array}$ & $\begin{array}{l}\text { LWG } \\
(\mathrm{kg} / \mathrm{ha})^{1}\end{array}$ & $\begin{array}{l}\text { Total LWG } \\
(\mathrm{kg} / \mathrm{mob})^{2}\end{array}$ \\
\hline Friesian & 43 & $199.1 \pm 2.38$ & $501.0 \pm 5.31$ & $0.97 \pm 0.02$ & 1141 & 12982 \\
\hline Jersey $\mathrm{x}$ & 46 & $184.8 \pm 2.87$ & $465.7 \pm 6.32$ & $0.90 \pm 0.03$ & 1151 & 12922 \\
\hline $\begin{array}{l}\text { Significance } \\
(P<0.001)\end{array}$ & & $\star * *$ & $* * *$ & $* * *$ & & \\
\hline
\end{tabular}

${ }^{1}$ Liveweight gain per hectare between 9 June and 20 December

${ }^{2}$ Total liveweight gains of each breed group between 9 June and 18 April 2000 . Extra areas were allocated to each group on 20 December 2000 so it was not possible to calculate total per hectare production over the whole experiment. 
over the whole period. Nevertheless, total areas available to each paired replicate (lane) were similar and the comparable liveweight gain figures over the experimental period were $12982 \mathrm{~kg}$ for the Friesian type and $12922 \mathrm{~kg}$ for the Jersey x type bulls. This represented an advantage of $0.5 \%$ for the Friesian bulls.

\section{Summary}

Although Friesian type bulls generally outperformed Jersey $\mathrm{x}$ type bulls on a per-head basis, there was considerable overlap in performance in animals within the Friesian type and Jersey $x$ type genotypes. The prejudice against calves which are not marked as typical "Friesian type" means that calves which could be reared for bull beef production are being slaughtered as bobby calves.

When the two breed types were stocked at a similar liveweight per hectare there was very little difference in terms of per-hectare production. This reinforces the findings of Everitt \& Ward (1974) that an increased stocking rate of lighter Jersey $\mathrm{x}$ Friesian bulls can achieve a similar output of carcass weight per hectare to Friesian bulls. It also confirms our belief that there is likely to be little or no difference between the breeds in the efficiency of converting grass to carcass weight. Jersey $\mathrm{x}$ type carcasses are likely to be slaughtered in lighter (and less lucrative) carcass weight grades, thus the purchase cost of store bulls needs to reflect this. As an example, the Jersey $x$ type bulls in Experiment 1 were, on average, $20 \mathrm{~kg}$ lighter than the Friesian type bulls and tended to have more individuals in the lighter carcass weight ranges (Table 4). As of 27 June 2001 , the penalty was $5 \mathrm{c} / \mathrm{kg}$ carcass for each carcass weight range (Table 4). An overall analysis of the carcass weights for Experiment 1 but using recent prices, indicates that the overall penalty for the Jersey $\mathrm{x}$ type bulls in Experiment 1 would be 4 cents $/ \mathrm{kg}$. Thus the Jersey $\mathrm{x}$ type bulls in Experiment 1 which averaged $271 \mathrm{~kg}$ carcass weight would need to have been purchased at a discount of approximately \$11/ head to cover the penalty attributable to lower carcass weight ranges. Current discounts for Jersey $x$ type bulls are well in excess of this and may reflect the difficulties in re-selling Jersey $x$ type bulls and perceived behavioural problems with these bulls. It must also be emphasised that the profitability of Jersey $\mathrm{x}$ type bulls is very sensitive to the discounts applying to the various weight ranges.

In Experiment $1,1 / 2$ Jersey $x$ Friesian calves were heavier than $35 \mathrm{~kg}$ at 4 days of age when procured for rearing. Calf weights were not available for calves in Experiments 2 and 3 nor was the precise percentage of Jersey blood. However, it can be reasonably expected they were of a suitable size when purchased for rearing (e.g., over $35 \mathrm{~kg}$ in liveweight). These experiments and findings pertain to Jersey $\mathrm{x}$ type calves of a reasonable birthweight. Light birthweight calves more likely to be slaughtered in very light weight ranges (e.g., $<220 \mathrm{~kg}$ ) and historically the penalty for these lighter carcasses has been quite marked.

Given the crossbred nature of the New Zealand dairy herd, coat colour does not seem to be the most appropriate method of selecting or rejecting calves for rearing. Since all $\mathrm{AB}$ dairy calves can be assigned a breeding value (BV) for liveweight based on the performance of their parents, this may provide a better mechanism than coat colour for identifying potentially better performing calves. At present, the best method of selecting a calf for rearing is still likely to be based on weight and frame size.

\section{ACKNOWLEDGEMENTS}

This work was undertaken as part of the Poukawa Calf Rearing Project with funding from MEAT NZ, AGMARDT, PCL Feeds, Ngahiwi Farms and the New Zealand Holstein Friesian Association. Special thanks go to Shane Hill of Whatawhata and Mike and Sarah Moss of Raglan for management of the bulls in Experiment 1, Simon Beamish and Greg Wilson for management of the bulls in Experiment 2 and Angus Mabin and Paul Jackson for management of the bulls in Experiment 3.

Table $\llbracket 4$ Distribution of carcass weights of Friesian and $1 / 2$ Jersey $/ 1 \frac{1}{2}$ Friesian bulls slaughtered in Experiment 1 . Indicative prices for the different weight ranges are as at 27 June 2001.

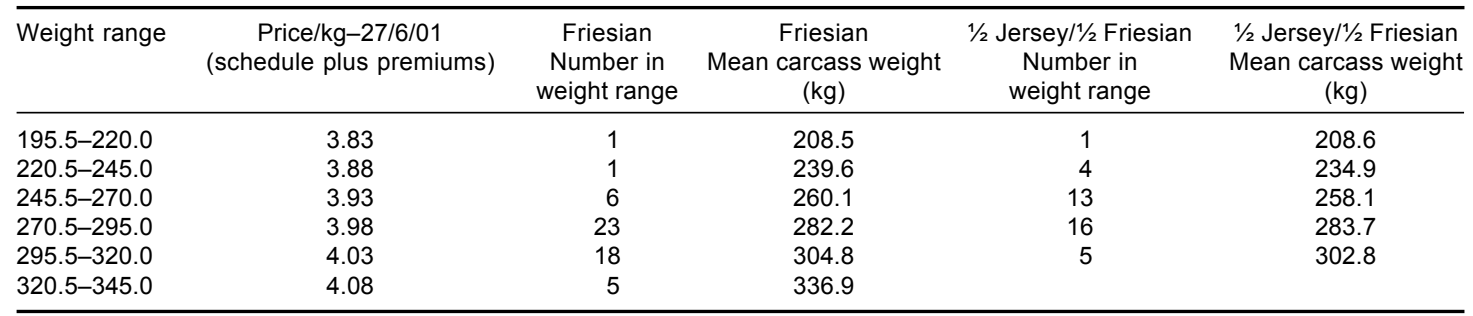




\section{REFERENCES}

Anon 2000. Dairy Statistics 1999/2000, Livestock Improvement Corporation Ltd.

Barton, R.A.; Donaldson, J.L.; Barnes, F.R.; Jones, C.F. and Clifford, H.J. 1994. Comparison of Friesian, Friesian-Jersey-cross and Jersey steers in beef production. New Zealand Journal of Agricultural Research 37: 51-58.

Candy, R.A; McAdam, M. 1966. Farming of Dairy Beef. Proceedings of the $18^{\text {th }}$ Ruakura Farmers' Conference: $70-71$.
Everitt, G.C; Ward, J.D.B. 1974. Bull beef production. Proceedings of the $26^{\text {th }}$ Ruakura Farmers' Conference: 81-96.

Joblin, A.D.H. 1966. Friesian x Jerseys for beef. Proceedings of the $18^{\text {th }}$ Ruakura Farmers' Conference: 64-70.

Muir, P.D.; Nieuwenhuis, G.; Smith, N.B; Ormond, A.W.A. 2000. A comparison of rearing systems for dairy beef calves. Proceedings of the New Zealand Grassland Association 62: 9-11

Ogle, G; Tither, P. 2000. An analysis of the risks and benefits of beef intensification. Proceedings of the New Zealand Grassland Association 62: 25-29. 